\title{
PENTINGNYA PERAN STRATEGI SUMBER DAYA MANUSIA DALAM MEMPENGARUHI RETENSI AUDITOR DI INDONESIA
}

\author{
Rudi Candra \\ Universitas Internasional Batam \\ rudi.candra@uib.edu
}

\begin{abstract}
Abstrak The purpose of this study was to analyze the influence of strategic human resource management to employee retention in audit firm using perceived organization support as a mediator variable. The samples in this study is the employee who work as auditor in audit firms in Indonesia. Method of data collection is conducted using questionnaire which distributed by e-mail to audit firms. Sampling method used in this study is purposive sampling. The amount of respondent in this study was 109 questionnaires which distributed among 11 city in Indonesia. The results of this study show that recruitment, training, compensation, and perceived organization support are parcially have a positive affect employee retention. Performance appraisal parcially do not affect employee retention. Strategic human resource management have a significant positive affect to perceived organizational support. The relationship between strategic human resource management and employee retention is fully mediated by perceived organizational support.
\end{abstract}

Kata Kunci recruitment, performance appraisal, compensation, perceived organizational support, employee retention.

\section{PENDAHULUAN}

Tenaga kerja merupakan sumber daya yang sangat penting bagi suatu perusahaan sehingga manajemen tenaga kerja pada suatu perusahaan harus diperhatikan. Menurut penelitian yang dilakukan oleh Belete (2018) terdapat beberapa faktor yang menyebabkan karyawan ingin berhenti dari suatu perusahaan misalnya kepuasan kerja, stres kerja, budaya organisasi, komitmen organisasi, gaji, keadilan organisasi, peluang promosi, variabel demografis, gaya kepemimpinan, dan iklim organisasi. Manajemen sumber daya manusia pada suatu perusahaan dapat mempengaruhi persepsi karyawan dalam menilai kepedulian perusahaan terhadap karyawan atau yang disebut sebagai perceived organizational support (Al-Hawary \& Nusair, 2017). Penelitian yang dilakukan oleh Abraham et al. (2016) membuktikan bahwa semakin tinggi kepedulian perusahaan terhadap karyawan maka akan mendorong karyawan untuk semakin bertahan dan tidak memiliki keinginan untuk berhenti. Oleh karena itu, perusahaan harus memiliki strategi yang tepat dalam melakukan manajemen tenaga kerja.

Strategi manajemen tenaga kerja yang dirancang oleh perusahaan akan mendukung perusahaan dalam mencapai tujuan perusahaan (Dessler, 2013). Oleh karena itu, personalia harus menentukan kebijakan yang dapat mendukung aktivitas personalia. Adapun contoh aktivitas personalia antara lain kegiatan rekrutmen, pemberian pelatihan, penilaian kinerja dan pemberiaan kompensasi kepada karyawan. Pelaksanaan aktivitas personalia sangat mempengaruhi kualitas hubungan karyawan dan perusahaan. Mayes et al. (2016) menemukan bahwa apabila praktik sumber daya manusia yang diterapkan oleh perusahaan dapat mendukung karyawan maka karyawan akan senang dalam membantu perusahaan dan bertahan pada perusahaan tersebut.

Kegiatan untuk mempertahankan karyawan merupakan suatu tantangan yang baru bagi perusahaan. Hal ini dikarenakan semakin terbukanya kesempatan untuk bekerja pada perusahaan multinasional akan berdampak pada perusahaan dalam mempertahankan karyawan yang 
kompeten. Menurut Fahim (2018), mempertahankan karyawan yang bernilai merupakan hal yang sulit bagi suatu perusahaan dikarenakan meningkatnya persaingan perusahaan sehingga upaya untuk mempertahankan karyawan merupakan strategi yang penting bagi personalia. Menurut Azeez (2017), retensi karyawan berkaitan erat dengan tingkat employee turnover. Dengan kata lain, apabila suatu perusahaan melakukan manajemen tenaga kerja dengan baik maka tingkat turnover karyawan pun akan rendah (Azeez, 2017). Persepsi dari dukungan organisasional yang dirasakan oleh karyawan akan mendorong karyawan semakin bersemangat dalam bekerja.

Menurut kompas.com (2019) jumlah auditor di Indonesia masih sedikit dibandingkan kebutuhan perusahaan yang memerlukan jasa audit. Kemampuan Kantor Akuntan Publik (KAP) dalam mempertahankan karyawan merupakan tantangan yang harus dihadapi oleh KAP. Keberhasilan KAP dalam mempertahankan karyawan yang bernilai dapat dilihat dari tingkat turnover karyawan. Beberapa faktor yang menyebabkan tingginya turnover menurut Nurkholis et al (2019) yaitu kepuasan gaji, kepuasan kerja, koflik peran kerja, Ambiguitas peran kerja. Faktor tersebut merupakan bagian dari penerapan strategi manajemen tenaga kerja yang perlu diperhatikan oleh KAP. Tingkat turnover karyawan pada salah satu KAP terbesar di Indonesia yang diperoleh melalui Laporan Transparansi Kantor Akuntan Publik PwC menunjukkan tingkat turnover karyawan pada KAP PwC sebesar 21\% pada tahun 2016. Data tersebut menunjukkan bahwa tingkat karyawan yang ingin berhenti bekerja pada KAP PwC tergolong cukup tinggi (PwC, 2017). Data penurunan staff audit dari KAP KPMG menunjukkan bahwa terjadi penurunan angka staff audit layanan klien yaitu dari jumlah 456 tahun 2017 (KPMG, 2017) menjadi 447 tahun 2018 (KPMG, 2018).

\section{LANDASAN TEORI}

\section{STRATEGI MANAJEMEN SUMBER DAYA MANUSIA}

Strategi Manajemen Sumber Daya Manusia (Strategi MSDM) merupakan suatu kesatuan fungsi yang berkaitan dengan pengelolaan modal manusia (Human Capital) dimana personalia berperan sebagai mitra eksekutif perusahaan dalam menjalankan strategi perusahaan (Fahim, 2018). Setiap aktivitas yang dilakukan dalam perumusan kebijakan sumber daya manusia bertujuan untuk menghasilkan kompetensi karyawan yang dapat membantu perusahaan dalam mencapai tujuan perusahaan (Dessler, 2013). Penerapan kebijakan sumber daya manusia yang efisien dapat membantu menciptakan hubungan yang kompetitif antara karyawan dengan perusahaan sehingga akan menurunkan tingkat turnover karyawan (Fahim, 2018). Selain menciptakan sinergi antara karyawan dengan perusahaan, penerapan kebijakan sumber daya manusia sangat penting untuk dapat mencapai keberhasilan perusahaan dalam jangka Panjang (Mahmood et al., 2018).

\section{REKRUTMEN}

Rekrutmen merupakan suatu proses untuk mencari sejumlah calon kandidat yang potensial untuk ditempatkan pada posisi tertentu sesuai kebutuhan perusahaan (Dowling, 2013). Perekrutan karyawan yang dilakukan secara efektif akan meningkatkan kepuasan karyawan yang mendorong karyawan ingin bertahan lama dalam bekerja pada perusahaan (Mbugua et al., 2015). Oleh karena itu, proses rekrutmen akan berpengaruh secara positif terhadap keinginan karyawan untuk bertahan pada suatu perusahaan (Mbugua et al., 2015).

\section{PELATIHAN}

Pelatihan adalah segala aktivitas yang dilakukan oleh perusahaan dalam rangka membantu karyawannya dalam memperoleh keahlian dan pengalaman yang dibutuhkan dalam melaksanakan perkerjaan (Francis, 2014). Pelatihan yang diberikan kepada karyawan akan memberikan kesempatan kepada karyawan untuk mengasah kompetensi yang dimiliki sehingga karyawan menjadi lebih percaya diri dalam bekerja dan dapat bekerja dengan baik (Imna \& Hassan, 2015). Oleh karena itu, pelatihan yang diberikan kepada karyawan akan membantu perusahaan dalam mempertahankan karyawan.

\section{PENILAIAN KINERJA}


Penilaian kinerja diartikan sebagai suatu proses untuk mengevaluasi kinerja karyawan yang dilakukan untuk pengambilan keputusan dalam pengembangan karir karyawan (Francis, 2014). Penilaian kinerja karyawan dapat menimbulkan ketidakpuasan pada karyawan apabila karyawan yang dinilai tidak menerima penilaian yang dilakukan oleh atasan sehingga menimbulkan keinginan untuk berpindah kerja (Hong et al., 2012). Oleh karena itu, penilaian kinerja memberikan kontribusi dalam usaha retensi karyawan yang dilakukan oleh perusahaan karena penilaian kinerja membuktikan bahwa perusahaan peduli terhadap kinerja karyawan (Imna \& Hasan, 2015)

\section{KOMPENSASI}

Kompensasi adalah segala bentuk uang yang diberikan perusahaan kepada karyawan sebagai imbalan dari pekerjaan yang dilakukan (Hong et al.). Pemberian kompensasi akan mempengaruhi motivasi karyawan untuk bekerja pada suatu perusahaan (Hong et al., 2012). Semakin baik pengelolaan kompensasi karyawan pada suatu perusahaan maka semakin tinggi pula kepuasaan karyawan terhadap pekerjaannya sehingga karyawan akan bekerja lebih lama (Kakar et al., 2017). Oleh karena itu, pengelolaan kompensasi memiliki pengaruh yang signifikan dalam mempengaruhi keinginan karyawan untuk bertahan pada suatu perusahaan.

\section{PERSEPSI DUKUNGAN ORGANISASI}

Menurut Al-Hawary \& Nusair (2017), definisi dari persepsi dukungan organisasi adalah perhatian yang diberikan perusahaan terhadap kepuasan karyawan dan kesediaan perusahaan untuk membantu karyawan dalam segala hal. Semakin tinggi persepsi karyawan terhadap kepedulian perusahaan maka semakin tinggi tingkat kepuasan karyawan terhadap perusahaan sehingga karyawan tidak akan berniat untuk berpindah kerja (Banan, 2017). Oleh karena itu, persepsi dukungan organisasi berpengaruh signifikan positif terhadap retensi karyawan.

\section{STRATEGI MANAJEMEN SUMBER DAYA MANUSIA DAN PERSEPSI DUKUNGAN ORGANISASI}

Strategi manajemen sumber manusia adalah suatu desain atau implementasi dari kebijakan sumber daya manusia yang dipastikan dapat mendukung perusahaan dalam mencapai tujuan perusahan (Glarino, 2013). Serangkaian kebijakan yang telah diterapkan oleh perusahaan merupakan bentuk kepedulian perusahaan terhadap karyawan (Al-Hawary \& Nusair, 2017). Semakin karyawan mengerti tentang kebijakan MSDM yang diterapkan pada perusahaan maka akan semakin tinggi pula tingkat kesadaran karyawan terhadap dukungan yang diberikan perusahaan kepada karyawan (Al-Hawary \& Nusair, 2017). Oleh karena itu, penerapan strategi MSDM akan mempengaruhi persepsi karyawan terhadap dukungan perusahaan.

\section{STRATEGI MANAJEMEN SUMBER DAYA MANUSIA DAN RETENSI KARYAWAN DENGAN PERSEPSI DUKUNGAN ORGANISASI SEBAGAI VARIABEL MEDIASI}

Strategi MSDM yang efektif dapat membantu menciptakan lingkungan kerja yang nyaman dan meningkatkan kepuasan karyawan (Agustine \& Ssemugenyi, 2018). Kepuasan karyawan diukur melalui persepsi yang dimiliki karyawan terhadap keterlibatan perusahaan dalam menciptakan kesejahteraan karyawan yang disebut juga persepsi dukungan organisasi (Banan, 2017). Karyawan akan memiliki persepsi yang baik terhadap keterlibatan perusahaan apabila penerapan kebijakan personalia yang dilakukan dapat membangun dan memdukung pekerjaan sehingga akan meningkatkan kepuasan dan loyalitas karyawan (Al-Hawary \& Nusair, 2017). Apabila karyawan tidak dapat merasakan keterlibatan perusahaan dalam membantu kesejahteraan karyawan dari penerapan kebijakan personalia yang ada, maka karyawan cenderung akan merasa tidak puas dan memiliki keinginan untuk berhenti dari perusahaan tersebut.

\section{METODOLOGI PENELITIAN}


Penelitian ini dilakukan dengan mengirimkan kuesioner penelitian ke kantor akuntan publik di Indonesia dimana data kantor akuntan publik diperoleh dari Ikatan Akuntan Publik Indonesia (IAPI). Data kantor akuntan publik yang terdaftar pada IAPI adalah sebanyak 619 kantor. Teknik pengumpulan data dilakukan melalui penyebaran kuesioner melalui alamat surat elektronik (e-mail). Metode pengumpulan data yang dilakukan menggunakan metode sampel bertujuan (purposive sampling). Purposive sampling merupakan metode pengambilan sampel dengan memilih salah satu objek penelitian untuk memperoleh informasi yang dibutuhkan oleh peneliti yang tidak dapat diperoleh dari sumber lain (Taherdoost, 2020).

\section{HASIL PENELITIAN}

\subsection{ANALISA DEMOGRAFI RESPONDEN}

Berdasarkan penyebaran instrumen penelitian, terdapat 109 responden yang mengisi formular google dan memenuhi syarat penerimaan responden. Adapun klasifikasi dari responden terdapat pada Tabel 1 dan Tabel 2 sebagai berikut:

Tabel 1 Data Responden Berdasarkan Jenis Kelamin

\begin{tabular}{lcc}
\hline Jenis Kelamin & Frekuensi & Persentase \\
\hline Pria & 40 & 36.70 \\
Wanita & 69 & 63.30 \\
Total & $\mathbf{1 0 9}$ & $\mathbf{1 0 0 . 0 0}$ \\
\hline
\end{tabular}

Tabel 2 Data Responden Berdasarkan Kota Responden

\begin{tabular}{lcc}
\hline Demografi & Frekuensi & Persentase \\
\hline Banda Aceh & 1 & $00,92 \%$ \\
Bandung & 1 & $00,92 \%$ \\
Batam & 31 & $28,44 \%$ \\
Denpasar & 1 & $00,92 \%$ \\
Jakarta & 66 & $60,55 \%$ \\
Jambi & 2 & $01,83 \%$ \\
Kabupaten Bone & 1 & $00,92 \%$ \\
Palangkaraya & 1 & $00,92 \%$ \\
Semarang & 1 & $00,92 \%$ \\
Surabaya & 3 & $02,75 \%$ \\
Yogyakarta & 1 & $00,92 \%$ \\
Total & 109 & $100,00 \%$ \\
\hline
\end{tabular}

\subsection{UJI VALIDITAS DAN REALIBILITAS}

Adapun hasil uji validitas dan realibilitas yang diperoleh dalam penguji kualitas data dapat dilihat pada tabel berikut:

Tabel 4 Hasil Uji Validitas Konstruk

\begin{tabular}{|l|c|c|l|c|c|}
$\begin{array}{c}\text { Variabel } \\
\text { Independen }\end{array}$ & $\begin{array}{c}\text { Muatan } \\
\text { Faktor }\end{array}$ & Kesimpulan & \multicolumn{1}{|c|}{ Variabel Independen } & $\begin{array}{c}\text { Muatan } \\
\text { Faktor }\end{array}$ & Kesimpulan \\
\hline Rekrutmen 1 & 0,799 & Valid & Persepsi Dukungan Organisasi 1 & 0,781 & Valid \\
\hline Rekrutmen 2 & 0,752 & Valid & Persepsi Dukungan Organisasi 2 & 0,791 & Valid \\
\hline Rekrutmen 3 & 0.759 & Valid & Persepsi Dukungan Organisasi 3 & 0,822 & Valid \\
\hline Pelatihan 1 & 0,785 & Valid & Persepsi Dukungan Organisasi 4 & 0,833 & Valid \\
\hline Pelatihan 2 & 0,797 & Valid & Persepsi Dukungan Organisasi 5 & 0,758 & Valid \\
\hline Pelatihan 3 & 0,799 & Valid & Persepsi Dukungan Organisasi 6 & 0,881 & Valid \\
\hline Pelatihan 4 & 0,625 & Valid & Persepsi Dukungan Organisasi 7 & 0,777 & Valid \\
\hline Pelatihan 5 & 0,872 & Valid & Persepsi Dukungan Organisasi 8 & 0,793 & Valid \\
\hline Penilaian Kinerja 1 & 0.804 & Valid & Persepsi Dukungan Organisasi 9 & 0,821 & Valid \\
\hline Penilaian Kinerja 2 & 0,846 & Valid & Persepsi Dukungan Organisasi 10 & 0,751 & Valid \\
\hline Penilaian Kinerja 3 & 0,828 & Valid & Retensi 1 & 0,656 & Valid \\
\hline Penilaian Kinerja 4 & 0,717 & Valid & Retensi 2 & 0,813 & Valid \\
\hline Kompensasi 1 & 0,613 & Valid & Retensi 3 & 0,864 & Valid \\
\hline Kompensasi 2 & 0,836 & Valid & Retensi 4 & 0,845 & Valid \\
\hline Kompensasi 3 & 0,845 & Valid & Retensi 5 & 0,783 & Valid \\
\hline
\end{tabular}




\begin{tabular}{|c|c|c|l|c|c|}
\hline $\begin{array}{c}\text { Variabel } \\
\text { Independen }\end{array}$ & $\begin{array}{c}\text { Muatan } \\
\text { Faktor }\end{array}$ & Kesimpulan & \multicolumn{1}{|c|}{ Variabel Independen } & $\begin{array}{c}\text { Muatan } \\
\text { Faktor }\end{array}$ & Kesimpulan \\
\hline Kompensasi 4 & 0.809 & Valid & Retensi 6 & 0,647 & Valid \\
\hline
\end{tabular}

Tabel 5 Hasil Uji Reabilitas

\begin{tabular}{lll}
\hline Variabel Independen & Cronbach's Alpha & Kesimpulan \\
\hline Rekrutmen & 0,657 & Data Realibel \\
Pelatihan & 0,822 & Data Realibel \\
Penilaian Kinerja & 0.796 & Data Realibel \\
Kompensasi & 0,782 & Data Realibel \\
Persepsi Dukungan Organisasi & 0.937 & Data Realibel \\
Retensi & 0.902 & Data Realibel \\
\hline
\end{tabular}

\subsection{UJI OUTLIER}

Hasil uji outlier menggunakan uji z-score dari 109 data responden tidak terdapat data residual yang lebih besar dari 3 ataupun lebih kecil dari -3. Oleh karena itu, seluruh data dapat digunakan untuk uji regresi tahap selanjutnya.

\subsection{UJI NORMALITAS}

Hasil uji normalitas pada grafik normal probability plot tersebar secara merata mendekati garis diagonal sehingga persebaran data tersebar secara normal. Hasil uji normalitas ditunjukkan oleh pada gambar berikut:

\subsection{UJI MULTIKOLINEARITAS}

Gambar 3 Hasil Uji Normalitas

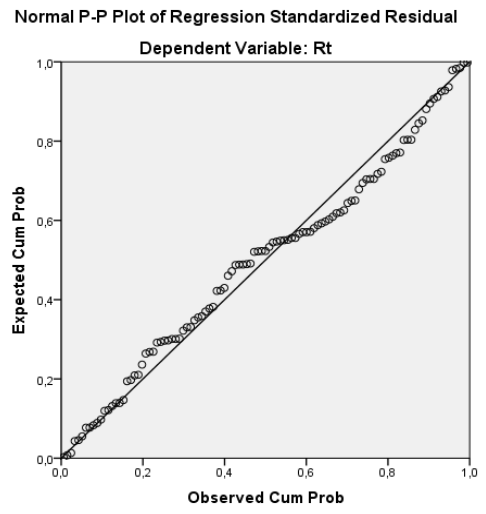

Tabel 6 Hasil Uji Multikolinearitas Strategi Manajemen SDM dan Retensi Karyawan dengan Persepsi Dukungan Organisasi sebagai Variabel Mediasi

\begin{tabular}{llll}
\hline \multirow{2}{*}{ Variabel Independen } & \multicolumn{2}{l}{ Collinearity Statistics } & \multirow{2}{*}{ Kesimpulan } \\
\cline { 2 - 3 } & Tolerance & VIF & \\
\hline Strategi Manajemen SDM &, 384 & 2,606 & Tidak terjadi multikolinearitas \\
Persepsi Dukungan Organisasi &, 384 & 2,606 & Tidak terjadi multikolinearitas \\
\hline
\end{tabular}

Hasil penelitian menunjukkan bahwa tidak ada korelasi antar variabel independen. Hal ini ditunjukkan melalui nilai VIF di bawah angka 10 dan nilai tolerance di atas 0,1 .

\subsection{UJI HIPOTESIS}

\subsubsection{UJI F}

Tabel 7 Hasil Uji F variabel Rekrutmen, Pelatihan, Penilaian Kinerja, Kompensasi dan Persepsi Dukungan Organisasi terhadap Retensi karyawan.

\begin{tabular}{ll}
\hline Model & Signifikan \\
\hline Regression & 0.000 \\
\hline
\end{tabular}

Berdasarkan Tabel 7 dapat dilihat bahwa variabel independen yaitu rekrutmen, pelatihan, penilaian kinerja, dan kompensasi serta variabel persepsi dukungan organisasi sebagai variabel mediasi secara simultan berpengaruh signifikan terhadap retensi karyawan.

Tabel 8 Hasil Uji f variabel Rekrutmen, Pelatihan, Penilaian Kinerja, dan Kompensasi terhadap Retensi karyawan

\begin{tabular}{ll}
\hline Model & Signifikan \\
\hline Regression & 0.000 \\
\hline
\end{tabular}

Berdasarkan Tabel 8 dapat dilihat bahwa variabel rekrutmen, pelatihan, penilaian kinerja, dan kompensasi secara simultan berpengaruh signifikan terhadap retensi karyawan.

\subsubsection{UJI T}

Tabel 9 Hasil Uji t variabel Rekrutmen, Pelatihan, Penilaian Kinerja, Kompensasi terhadap Retensi karyawan. 


\begin{tabular}{lrrc}
\hline Variabel Independen & Koefisien B & \multicolumn{1}{c}{ Sig. } & Kesimpulan \\
\hline Rekrutmen &, 860 &, 004 & Signifikan Positif \\
Pelatihan &, 403 &, 042 & Signifikan Positif \\
Peniliaian Kinerja &,- 083 &, 717 & Tidak Signifikan \\
Kompensasi &, 584 &, 013 & Signifikan Positif \\
\hline
\end{tabular}

Hasil uji pada Tabel 9 menunjukkan proses rekrutmen memiliki pengaruh secara signifikan positif terhadap retensi karyawan. Hasil ini menunjukkan bahwa apabila terjadi peningkatan pada variabel kompensasi sebesar 1 maka retensi karyawan pun akan meningkat sebesar 0,860 . Hal ini dikarenakan proses rekrutmen akan memudahkan calon auditor untuk mengenal pekerjaan yang akan dilamar sehingga kandidat karyawan dapat memperhatikan secara seksama persyaratan sebelum menerima pekerjaan. Oleh karena itu, pemberian kebijakan rekrutmen yang baik akan membantu menyaring dan meningkatkan retensi karyawan. Hasil ini sama dengan penelitian Paul \& Hung (2018), Fahim (2018), Abdoulaye (2017), Olaimat \& Awwad (2017), Santhanam et al. (2017), Mbugua et al. (2015) dan Maina \& Waiganjo (2014) yang menunjukkan pengaruh signifikan positif antara variabel rekrutmen terhadap retensi karyawan. Berdasarkan hasil analisis yang diperoleh maka hipotesis pertama terbukti.

Hasil uji pada Tabel 9 menunjukkan pelatihan yang diberikan oleh kantor akuntan publik berpengaruh secara signifikan positif terhadap retensi karyawan. Hasil ini menunjukkan bahwa apabila terjadi peningkatan pada variabel kompensasi sebesar 1 maka retensi karyawan pun akan meningkat sebesar 0,403 . Hal ini dikarenakan dengan adanya pelatihan yang diterima oleh auditor maka auditor akan memiliki tambahan kompetensi yang dapat dimanfaatkan oleh auditor untuk meningkatkan produktivitas dan efisiensi saat bekerja. Hasil ini sama dengan penelitian Roy (2019), Mugizi et al. (2019), Mahmood et al. (2018), Fahim (2018), Gupta \& Gomathi (2018), Abdoulaye (2017), Olaimat \& Awwad (2017), Kakar et al. (2017), Santhanam et al. (2017), Abesiri \& Jayasekara (2016), Maina \& Waiganjo (2014), Tangthong et al. (2014), Agustine \& Ssemugenyi (2014) dan Hong et al. (2012) yang menunjukkan bahwa pengembangan dan pelatihan yang diberikan ke auditor berdampak terhadap keinginan auditor untuk bertahan lama pada kantor akuntan publik. Berdasarkan hasil analisis yang diperoleh maka hipotesis kedua terbukti.

Hasil uji pada Tabel 9 menunjukkan penilaian kinerja yang dilakukan oleh Kantor Akuntan Publik tidak berpengaruh terhadap retensi karyawan. Penilaian kinerja berfungsi untuk meningkatkan produktivitas dan kinerja karywan. Bagi seorang profesional, mayoritas auditor tidak terlalu memperhatikan penilaian kinerja. Hal ini dikarenakan meskipun penilaian kinerja yang diberikan mengakibatkan auditor tersebut kehilangan pekerjaannya, seorang auditor memiliki kompetensi yang dibutuhkan oleh perusahaan lain. Hasil ini konsisten dengan penelitian Mugizi et al. (2019), Paul \& Hung (2018), Olaimat \& Awwad (2017), Imna \& Hassan (2015) dan Francis (2014) yang mengemukakan bahwa penilaian kinerja bahwa tidak berpengaruh terhadap keputusan karyawan untuk bertahan pada suatu perusahaan. Berdasarkan hasil analisis yang diperoleh maka hipotesis ketiga tidak terbukti.

Hasil uji pada Tabel 9 menunjukkan bahwa pemberian kompensasi memiliki pengaruh secara signifikan positif terhadap retensi karyawan. Hasil ini menunjukkan bahwa apabila terjadi peningkatan pada variabel kompensasi sebesar 1 maka retensi karyawan pun akan meningkat sebesar 0.584 . Penentuan nilai kompensasi yang baik akan memberikan kepuasan kepada auditor dikarenakan kerja keras yang dilakukan dapat dihargai dengan baik oleh manajemen kantor akuntan publik. Dengan demikian, pemberian kompensasi yang baik akan meningkatkan kesejahtraan auditor sehingga auditor akan setia pada kantor akuntan publik. Hasil ini selaras dengan penelitian Roy (2019), Gupta \& Gomathi (2018), Mahmood et al. (2018), Waweru \& Kagiri (2018), Abesiri \& Jayasekara (2016), Haider et al. (2015), dan Agustine \& Ssemugenyi (2014) yang menemukan bahwa semakin tinggi kompensasi yang diberikan maka akan semakin kecil tingkat turnover karyawan atau dengan kata lain karyawan akan memilih untuk bekerja 
dalam jangka lebih lama. Berdasarkan hasil analisis yang diperoleh maka hipotesis keempat terbukti.

Tabel 10 Hasil Uji t variabel Strategi Manajemen Sumber Daya Manusia terhadap Persepsi Dukungan Organisasi

\begin{tabular}{crrc}
\hline Variabel Independen & Koefisien B & Sig. & Kesimpulan \\
\hline Strategi Manajemen SDM & 0,584 &, 000 & Signifikan positif \\
\hline
\end{tabular}

Berdasarkan hasil uji pada Tabel 10, strategi manajemen sumber daya manusia yang ditetapkan oleh suatu perusahaan memberikan pengaruh yang signifikan positif terhadap persepsi dukungan organisasi yang dirasakan oleh auditor. Hal ini ditunjukkan oleh nilai signifikansi tabel sebesar 0,000 dan nilai koefisien sebesar 0,584. Pemberian kebijakan sumber daya manusia yang baik membuktikan bahwa kantor akuntan publik memperhatikan kebutuhan karyawan. Hasil ini sama dengan penelitian yang dilakukan oleh Martono \& Putri (2018), Mayes et al. (2017), Al33Hawary \& Nusair (2017), Adresi \& Darun (2015), Fatima et al. (2015), Glarino (2013), Narang \& Singh (2011), dan Edwards (2009) yang menemukan bahwa praktik kebijakan personalia secara signifikan positif mempengaruhi persepsi dukungan organisasi pada karyawan. Berdasarkan hasil analisis dapat disimpulkan bahwa hipotesis kelima terbukti.

Tabel 11 Hasil Uji t variabel Persepsi Dukungan Organisasi terhadap Retensi karyawan.

\begin{tabular}{crcc}
\hline Variabel Independen & Koefisien B & Sig. & Kesimpulan \\
\hline Persepsi Dukungan Organisasi &, 720 &, 000 & Signifikan Positif \\
\hline
\end{tabular}

Hasil uji pada Tabel 11 menunjukkan persepsi dukungan organisasi memiliki pengaruh yang signifikan positif terhadap retensi karyawan. Hal ini dikarenakan dengan adanya kebijakan perusahaan ataupun perlakukan kantor akuntan publik yang dapat meningkatkan persepsi auditor bahwa mereka dihargai dan penting bagi perusahaan maka akan membuat auditor menjadi nyaman dan ingin loyal terhadap kantor akuntan publik. Hasil ini sama dengan penelitian yang dilakukan oleh Fitria \& Linda (2019), Alfisyahri (2018), Ghazali et al. (2018), Treglown et al. (2018), Ashraf et al. (2016), Saranya \& Muthumani (2015) Kalidass \& Bahron (2015), Islam et al. (2013), Hussain \& Asif (2012) dan Tumwesigye (2010) yang menemukan bahwa persepsi dukungan organisasi memiliki hubungan yang signifikan positif terhadap retensi karyawan. Berdasarkan hasil analisis dapat disimpulkan bahwa hipotesis keenam terbukti.

\subsubsection{UJI HIPOTESIS VARIABEL MEDIASI}

Dalam menguji keberhasilan dari variabel mediasi dalam memediasi hubungan antara variabel independen dan variabel dependen dilakukan dengan menggunakan model uji mediasi oleh Baron dan Kenny (1986). Tabel 12 menunjukkan hasil uji t variabel mediasi:

Tabel 12 Uji Kriteria Mediasi

\begin{tabular}{lcc}
\hline Model Regresi & B & Sig \\
\hline Strategi Manajemen SDM terhadap Persepsi Dukungan Organisasi & 0,584 & 0,000 \\
Persepsi Dukungan Organisasi terhadap Retensi Karyawan & 0,720 & 0,000 \\
Strategi Manajemen SDM terhadap Retensi Karyawan & 0,406 & 0,000 \\
\hline
\end{tabular}

Setelah kriteria signifikansi ketiga regresi terpenuhi maka dilakukan regresi linear berganda dengan memasukkan variabel persepsi dukungan organisasi ke dalam regresi akhir. Berikut merupakan hasil regresi untuk pengujian mediasi:

Tabel 13 Uji Mediasi

\begin{tabular}{lcc}
\hline Variabel & B & Sig \\
\hline Strategi Manajemen SDM & 0,049 & 0,427 \\
Persepsi Dukungan Organisasi & 0,664 & 0,000 \\
\hline
\end{tabular}

Berdasarkan hasil uji pada Tabel 13, hubungan mediasi yang timbul antara variabel strategi manajemen SDM terhadap retensi karyawan melalui persepsi dukungan organisasi adalah hubungan mediasi penuh. Hal ini ditunjukkan melalui nilai signifikansi variabel strategi 
manajemen SDM sebesar 0.427. Berdasarkan hasil analisis tersebut dapat disimpulkan bahwa hipotesis ketujuh terbukti.

\subsubsection{UJI KOEFISIEN DETERMINASI (ADJUSTED $\boldsymbol{R}^{2}$ )}

Hasil uji koefisien determinasi (adjusted R2) pada penelitian ini ditunjukkan pada tabel dibawah ini:

Tabel 14 Hasil Uji Adjusted R2

\begin{tabular}{lcc}
\hline Model & $\begin{array}{c}\text { Adjusted } R \\
\text { Square }\end{array}$ & Persentase \\
\hline Strategi Manajemen SDM terhadap Retensi karyawan & 0,413 & $41.3 \%$ \\
Strategi Manajemen SDM terhadap Persepsi Dukungan Organisasi & 0.602 & $60.2 \%$ \\
Persepsi Dukungan Organisasi terhadap Retensi karyawan & 0.609 & $60.9 \%$ \\
\hline
\end{tabular}

\section{KESIMPULAN}

Kebijakan rekrutmen memiliki peran dalam mempengaruhi keputusan auditor untuk bertahan lama pada suatu kantor akuntan publik. Hal ini dikarenakan proses rekrutmen akan memudahkan calon auditor untuk mengenal pekerjaan yang akan dilamar sehingga kandidat karyawan dapat memperhatikan secara seksama persyaratan sebelum menerima pekerjaan. Oleh karena itu, pemberian kebijakan rekrutmen yang baik akan membantu menyaring dan meningkatkan efektivitas karyawan dan biaya rekrutment (Olaimat \& Awwad, 2017).

Pelatihan yang diterima karyawan memiliki pengaruh yang signifikan dalam mempengaruhi tingkat retensi auditor pada kantor akuntan publik. Hal ini dikarenakan dengan mengikuti pelatihan setiap karyawan akan memperoleh tambahan kompetensi yang dapat dimanfaatkan oleh karyawan untuk meningkatkan produktivitas dan efisiensi saat bekerja (Mugizi et al., 2019).

Penilaian kinerja yang dilakukan perusahaan tidak berpengaruh dalam meningkatkan retensi auditor. Penilaian kinerja berfungsi untuk meningkatkan produktivitas dan kinerja karywan. Bagi seorang profesional, mayoritas auditor tidak terlalu memperhatikan penilaian kinerja. Hal ini dikarenakan meskipun penilaian kinerja yang diberikan mengakibatkan auditor tersebut kehilangan pekerjaannya, seorang auditor memiliki kompetensi yang dibutuhkan oleh perusahaan sehingga auditor tidak menganggap penting penilaian kinerja perusahaan (Olaimat \& Awwad, 2017).

Kompensasi memiliki berpengaruh yang signifikan terhadap retensi auditor. Penentuan nilai kompensasi yang baik akan memberikan kepuasan kepada auditor dikarenakan kerja keras yang dilakukan dapat dihargai dengan baik oleh manajemen kantor akuntan publik. Dengan demikian, pemberian kompensasi yang baik akan meningkatkan kesejahtraan auditor sehingga auditor akan setia pada kantor akuntan publik (Wijesiri et al., 2019).

Persepsi karyawan terhadap dukungan yang diberikan oleh kantor akuntan publik akan mempengaruhi tingkat retensi karyawan secara signifikan positif. Pemberian kebijakan sumber daya manusia yang baik membuktikan bahwa kantor akuntan publik memperhatikan kebutuhan karyawan sehingga karyawan akan bertahan lama dalam bekerja (Banan, 2017).

Strategi Manajemen SDM berpengaruh secara signifikan positif terhadap persepsi dukungan organisasi. Hal ini dikarenakan dengan adanya kebijakan perusahaan ataupun perlakukan kantor akuntan publik yang dapat meningkatkan persepsi auditor bahwa mereka dihargai dan penting bagi perusahaan maka akan membuat auditor menjadi nyaman dan ingin loyal terhadap kantor akuntan publik (Al-Hawary \& Nusair, 2017).

Persepsi dukungan organisasi memediasi penuh hubungan antara variabel strategi manajemen SDM terhadap tingkat retensi karyawan.

\section{UCAPAN TERIMA KASIH}

Penulis mengucapkan terima kasih kepada Auditor yang telah menjadi responden pada penelitian ini karena telah meluangkan waktu untuk menyelesaikan pengisian kuesioner penulis. 
Selain itu, terima kasih juga penulis haturkan kepada rekan peneliti yang telah menyelesaikan penelitian terdahulu sehingga menjadi referensi bagi penulis dalam menyelesaikan penelitian.

\section{DAFTAR PUSTAKA}

Abesiri, H., \& Jayasekara, P. (2016). The Impact of Human Resource Management Practices on Retention of Factory Officers : A Study on Tea Plantation Sector in Kegalle District in Sri Lanka. Human Resource Management Journal, 4(2), 1-10.

Abraham, J., Renaud, S., \& Saulquin, J.-Y. (2016). Relationships between Organizational Support, Organizational Commitment and Retention: Evidence from High-Potential Employees. Global Journal of Business Research, 10(1), 11-26.

Adan., Akgunduz, Y., \& Alkan, C. (2017). The Effects of Job Stress and Perceived Organizational Support on Turnover Intentions of Hotel Employees. Journal of Tourismology, 3(2), 23-32.

Agustine, A. A., \& Ssemugenyi, F. (2014). The Influence Of Human Resource Management Practices On Employees Retention In Kenya Power Company Ltd. Global Journal of Commerce \& Management Perspective, 3(4), 74-78.

Ahmad, H., \& Qadir, M. (2018). Dimensions of Perceived Over Qualification, Perceived Organizational Support and Turnover Intentions. 3, 1, 18-33.F

Belete AK. (2018). Turnover Intention Influencing Factors of Employees: An Empirical Work Review. Journal of Entrepreneurship \& Organization Management, 07(03), 3-7.

Akhter, S., Malik, M. F., Khwaja, M. G., \& Mehmed, S. (2018). Flexible HRM Practices and Employee Retentiossn: Developing and Testing of an Integrated Model. International Journal of Modern Management Sciences, 7(1), 13-27.

Adresi, A. Al., \& Darun, M. R. (2017). Investigating mediating effect of perceived organizational support between SHRM practices and employee trust. International Journal of Engineering Business Management, 9, 1-10.

Alfisyahri, K., Etikariena, A., \& Gatari, E. (2018). The relationship between perceived organizational support and employeers turnover intention through supportive co-worker workshop in division B at Company X. Advances in Social Science, Education and Humanities Research (ASSEHR), 135, 464474.

Al-Hawary, S. I. S., \& Nusair, W. K. I. (2017). Impact of Human Resource Strategies on Perceived Organizational Support at Jordanian Public Universities. Global Journal of Management and Business Research, 17(1).

Arasanmi, C. N., \& Krishna, A. (2019). Employer branding: perceived organisational support and employee retention - the mediating role of organisational commitment. Industrial and Commercial Training, 51(3), 174-183.

Ashraf, M., Ahmad, N., \& Haider, S. (2016). Antecedents of Turnover Intentions : A Study Of Karachi Business Schools. Journal of Business Studies, 12(1), 139-156.

Azeez, S. (2017). Human Resource Management Practices and Employee Retention: A Review of Literature. Journal of Economics, Management and Trade, 18(2), 1-10.

Ba, A. (2017). A Research on HRM Factors Affecting Employee Retention at. European Journal of Business and Management, 9(19), 1-8.

Bai, S., \& Bhutto, M. (2016). HRM Practices in Improving Employee Retention in Pakistan, Where Employee Value as a Focal Point. Journal of Economics, Business and Management, 4(12), 677-683.

Banan, S. H. A. EL. (2017). Perceived Organizational Support, Psychological Empowerment and Intention to Stay among Staff Nurses at a Selected Hospital. International Journal of Nursing Didactics, 7(3).

Barlian, E. (2016). Metodologi Penelitian Kualitatif \& Kuantitatif.

Baron, R. M., \& Kenny, D. A. (1986). The moderator-mediator variable distinction in social psychological research: Conceptual, strategic, and statistical considerations. Journal of personality and social psychology, 51(6), 1173.

Chukwuka, E. J., \& Nwakoby, N. P. (2018). Effect of Human Resource Management Practices on Employee Retention and Performance in Nigerian Insurance Industry. International Journal of Business, Accounting and Management, 3(1), 2527-3531.

Darmika, N. K. A. P., \& Sriathi, A. A. A. (2019). Pengaruh Pengembangan Karier, Komitmen Organisasional Dan Perceived Organizational Support Terhadap Retensi Karyawan. 8(7), 4153-4182.

Dessler, G. (2013). Human Resource Management Thirteenth Edition. 
Dowling, P., Festing, M., \& Engle, A. D. (2013). International Human Resource Management Sixth Edition. Cengage Learning.

Duarte, A. P., Gomes, D. R., \& Neves, J. G. (2015). Satisfaction with human resource management practices and turnover intention in a five-star hotel: The mediating role of perceived organizational support. Dos Algarves A Multidisciplinary E-Journal, 25(June 2016), 103-123.

Edwards, M. R. (2009). HR, perceived organisational support and organisational identification: An analysis after organisational formation. Human Resource Management Journal, 19(1), 91-115.

Fahim, M. G. A. (2018). Strategic human resource management and public employee retention. Review of Economics and Political Science, 3(2), 20-39.

Fatima, M., Shafique, M., Qadeer, F., \& Ahmad, R. (2015). HR practices and employee performance relationship in higher education: Mediating role of job embeddedness, perceived organizational support and trust. Pakistan Journal of Statistics and Operation Research, 11(3), 421-439.

Fayaz, M., Amin, K., \& Khan, N. (2019). Factors Affecting Employees Turnover Intentions in Khyber Pukhthunkhwa-Pakistan (A case Study of Habib Banks Limited, Peshawar Region). SSRN Electronic Journal, 1-14.

Fitria, Y., \& Linda, M. R. (2019). Perceived Organizational Support and Work Life Balance on Employee Turnover Intention. Advances in Economics, Business and Management Research, 65(Icebef 2018), 503-506.

Francis, A. U. (2014). Human Resource Management Practices and Employee retention in Nigeria's Manufacturing industries. International Journal of Scientific \& Engineering Research, 5(2), 1741-1754.

Ghazali, H., Nashuki, N. M., \& Othman, M. (2018). The Influence of Perceived Organizational Support (POS), Perceived Supervisory Support (PSS) and Organizational Commitment (OC) towards Intention to Leave or Intention to Stay: A case of Casual Dining Restaurants in Klang Valley, Malaysia. International Journal of Academic Research in Business and Social Sciences, 8(9), 1884-1902.

Glarino, G. G. (2013). Strategic Human Resource Management : Influences on Perceived Organizational Support and Job Attitudes. International Journal of Business and Social Science, 4(12), 6-16.

Gupta, A., \& Gomathi, S. (2018). Influence of human resource practices on faculty's intention to stay in higher education management institutes. International Journal of Business Excellence, 15(2), 256-268.

Haider, M., Rasli, A., Akhtar, C. S., Yusoff, R. B. M., Malik, O. M., Aamir, A., .. Tariq, F. (2015). The impact of human resource practices on employee retention in the telecom sector. International Journal of Economics and Financial Issues, 5(2), 63-69.

Hair, J.F., Black, W.C., Babin, B.J., \& Anderson, R.E. (2018) Multivariate Data Analysis. 8th Edition, United Kingdom: Cengage Learning

Hong, E., Hao, L., Kumar, R., Ramendran, C., \& Kadiresan, V. (2012). An effectiveness of human resource management practices on employee retention in institute of higher learning: A regression analysis. International Journal of Business Research and Management, 3(2), 60-79.

Hussain, T., \& Asif, S. (2012). Is Employees' Turnover Intention Driven By Organizational Commitment and Perceived Organizational Support? Journal of Quality and Technology Management, 8(2), 1-10.

Imna, M., \& Hassan, Z. (2015). Influence of Human Resource Management Practices on Employee Retention in Maldives Retail Industry. International Journal of Accounting and Business Management, 4(2), 50-80.

Islam, T., Khan, S. ur R., Ungku Ahmad, U. N. B., Ali, G., Ahmed, I., \& Bowra, Z. A. (2013). Turnover Intentions: The Influence of Perceived Organizational Support and Organizational Commitment. Procedia - Social and Behavioral Sciences, 103, 1238-1242.

Kakar, P., Raziq, A., \& Khan, F. (2017). Impact of Human Resource Management Practices on Employee Retention: A Case of Banking Sector in Quetta Baluchistan. Journal of Management Info, 4(3), 5-11.

Kalidass, A., \& Bahron, A. (2015). The Relationship between Perceived Supervisor Support, Perceived Organizational Support, Organizational Commitment and Employee Turnover Intention. International Journal of Business Administration, 6(5), 82-89.

Kompas.com. (2019). Kebutuhan Auditor Bertambah, IAPI Dorong Kompetensi Akuntan Publik. Retrieved from https://ekonomi.kompas.com/read/2019/01/25/123743826/kebutuhan-auditor-bertambah-iapidorong-kompetensi-akuntan-publik.

Kowo, S. A., ObaAdenuga, O. A., \& Sabitu, O. owotutu. (2019). Efficacy of E-recruitment Practices on Employee Retention in Multinational Corporations. Economics and Culture, 16(1), 161-171.

KPMG. (2017). Transparency Report KPMG.

KPMG. (2018). Transparency Report KPMG. 
Mahmood, N. A., Paiman, M., Mohammed, M. K., \& Suhaimee, M. S. (2018). The effectiveness of human resource management practices on employee retention at national hydrographic centre (NHC). The Journal of Social Sciences Research, (2), 285-296.

Maina, B. W. (2014). Effect of Human Resource Management Practices on Employees Retention in Institutions of Higher Learning in Kenya : a Case Study of Kenyatta University. Journal Management, 2(14), 256-279.

Martono, S., \& Putri, V. W. (2018). HRM Practices in Indonesia: the Contributing Power of Embeddedness and Support. Jurnal Dinamika Manajemen, 9(2), 206-217.

Mayes, B. T., Finney, T. G., Johnson, T. W., Shen, J., \& Yi, L. (2016). The effect of human resource practices on perceived organizational support in the People's Republic of China. International Journal of Human Resource Management, 28(9), 1261-1290.

Mbugua, G. M., Waiganjo, E. W., \& Njeru, A. (2014). Relationship between Strategic Recruitment and Employee Retention in Commercial Banks in Kenya. International Journal of Business Administration, 6(1), 87-97.

Mugizi, W., Musinguzi, M. N., \& Augustina, D. O. (2019). Human Resource Career Development Practices and Retention of Secondary Schools' Teachers in Rubabo County, Rukungiri District, Uganda. Journal of Education Research and Rural Community Development, 1(2), 18-20.

Nadeem, K., Khan, M. A., Imtiaz, N., \& Iftikhar, Y. (2019). Turnover Intention and Perceived Organizational Support; Mediating Role of Work Engagement and Organizational Commitment. European Scientific Journal, 15(10).

Narang, L., \& Singh, L. (2011). Human Resource Practices and Perceived Organizational Support - A Relationship in Indian Context. Management and Labour Studies, 36(3), 217-224.

Nurkholis, I. P. H. S., \& Hariadi, B. (2019). Turnover Intention in Public Accounting Firms in East Java. Journal Of Accounting And Business Education, 3(2), 123-140.

Nyaema, R. W., \& Wambua, D. P. (2017). Strategic Human Resource Management Practices and Employee Retention in Commercial Banks in Kenya. Journal of Human Resource and Leadership, 4(2), 73-89.

Oladunmoye, E. O. (2017). A Regression Analysis Of Perceived Organizational Support, Interpersonal Relationship And Employee Turnover Intention In Southwest Nigeria. International Journal of Information, Business and Management, 9(3).

Olaimat, D., \& Awwad, B. (2017). Exploring the Relationship between Human Resource Practices and Employee Retention in the House of Representatives in Jordan. International Journal of Business and Social Science, 8(10), 178-185.

Paul, G. D., \& Hung, D. K. M. (2018). Human resource management practices and turnover intention : The mediating role of perceived organizational support in tertiary institutions in Nigeria. International Journal of Engineering \& Technology, 7(3), 715-722.

PWC. (2017). Transparency report: A conversation on transparency, quality, and value.

Rasdi, R. M., \& Chen, Y. S. (2018). People Management for Managing Employees' Retention in the Organizations. International Journal of Academic Research in Business and Social Sciences, 8(12), 499-509.

Roy, B. (2019). Influence Of Human Resource Management Practices On Employee Retention: A Study In Banks. International Journal of Accounting and Business Management, 4(1), 50-80.

Saleem, M., \& Affandi, H. (2014). HR Practices and Employees Retention, an empirical analysis of Pharmaceutical sector of Pakistan. IOSR Journal of Business and Management, 16(6), 111-116.

Santhanam, N., Kamalanabhan, T. J., Dyaram, L., \& Ziegler, H. (2017). Impact of human resource management practices on employee turnover intentions: Moderating role of psychological contract breach. Journal of Indian Business Research, 9(3), 212-228.

Saranya, R., \& Muthumani1, S. (2015). Impact of perceived organisation support and organisation commitment on turnover intention of women employees in it industry. Journal of Theoretical and Applied Information Technology, 75(2), 256-261.

Satardien, M., Jano, R., \& Mahembe, B. (2019). The relationship between perceived organisational support, organisational commitment and turnover intention among employees in a selected organisation in the aviation industry. South African Journal of Childhood Education, 17, 1-8.

Setiawan, Adi. (2017) Analisis data statistik. Salatiga. Tisara Grafika,

Shah, M., \& Asad, M. (2018). Effect of Motivation on Employee Retention: Mediating Role of Perceived Organizational Support. European Online Journal of Natural and Social Sciences, 7(2), 511-520. 
Sugiyono. (2013). Metode Penelitian Pendidikan Pendekatan Kuantitatif, Kualitatif, dan R\&D. Bandung: Alfabeta

Tangthong, S., Trimetsoontorn, J., \& Rojniruntikul, N. (2014). HRM Practices and Employee Retention in Thailand-A Literature Review. International Journal of Trade, Economics and Finance, 5(2), 162166.

Tokmak, I., \& Turen, U. (2012). Exploring the Effect of Human Resource Management Practices on Organizational Performance and the Mediating Role of Perceived Organization Support : An Empirical Research on Turkish SMEs 1. European Journal of Social Sciences, 36(2), 253-262.

Treglown, L., Zivkov, K., Zarola, A., \& Furnham, A. (2018). Intention to quit and the role of dark personality and perceived organizational support: A moderation and mediation model. PLoS ONE, 13(3), 1-13.

Tumwesigye, G. (2010). The relationship between perceived organisational support and turnover intentions in a developing country: The mediating role of organisational commitment. African Journal of Business Management, 4(6), 942-952.

Waweru, S. W., \& Kagiri, A. (2018). Effect Of Human Resource Management Strategies On Employee Retention: A Survey Of Agriculture Sector Ngos Based In Nairobi, Kenya. Strategic Journal of Business \& Change Management, 5(2), 2340-2360.

Wibowo, A. (2012). Aplikasi Praktis SPSS dalam Penelitian (1st ed.). Yogyakarta: Gava Media. Wijesiri, N. R. A. S. S., Paranagama, G. S., Sirirwardhana, M. M. A. S., Thilakarathna, D. L. N. C.,

Weerarathna, R. ., \& Pathirana, U. P. G. . (2019). The Impact of HR Practices on Employee Retention; A Case of BPO Sector, Sri Lanka. International Journal of Human Resource Studies, 9(1), 1.

Xiaoyu, L., Zhang, Y., Yan, D., Wen, F., \& Zhang, Y. (2020). Nurses' intention to stay: The impact of perceived organizational support, job control and job satisfaction. Journal of Advanced Nursing.

Zin, M. L. B. M. (2017). The Mediating Role of Perceived Organizational Support on the Relationship between Pay and Intention to Stay. Management Review: An International Journal, 12(1), 57-77. 